\title{
Physiological functions of phlorotannins
}

\author{
Valeriya Lemesheva ${ }^{1}$ and Elena Tarakhovskaya ${ }^{1,2}$ \\ 1Department of Plant Physiology and Biochemistry, Faculty of Biology, \\ Saint Petersburg State University, Universitetskaya nab. 7-9, Saint Petersburg, 199034, \\ Russian Federation; \\ ${ }^{2}$ Russian Academy of Sciences Library, Birzhevaia Liniia 1, Saint Petersburg, 199034, \\ Russian Federation \\ Address correspondence and requests for materials to Elena Tarakhovskaya, \\ elena.tarakhovskaya@gmail.com
}

\begin{abstract}
Phlorotannins are the most abundant group of metabolites specific for brown algae. These substances contribute both to the primary and secondary metabolism of the algal cells and have practical relevance as biologically active compounds. The list of their presumable physiological functions is still not exhaustive and includes wound healing, chelation of heavy metal ions, bioadhesion, contribution to the processes of algal early embryogenesis and sporogenesis, etc. Similar to higher plant phenolics, phlorotannins also have antioxidant properties, provide chemical defense against herbivores and contribute to cell wall rigidification. The complex and diverse composition of natural phlorotannins hampers investigation of their physiological roles and leads to inconsistencies in the obtained data. Further study of the correlation between the structure of these substances and their functions is needed to take a new look at known information, thus providing better performance in the fields of both fundamental algal physiology and applied phycology.
\end{abstract}

Keywords: phlorotannins, brown algae, phenolic compounds, cell wall, physodes, algal exudates, bioadhesion, antifouling compounds

\section{General description of phlorotannins}

Citation: Citation: Lemesheva, V. and Tarakhovskaya, E. 2018. Physiological functions of phlorotannins. Bio. Comm. 63(1): 70-76. https://doi.org/10.21638/ spbu03.2018.108

Author's information: Valeriya Lemesheva, student; Elena Tarakhovskaya, Ph.D., Associate Professor, orcid.org/0000-0002$5341-2813$

Manuscript Editor: Farida Minibayeva, Kazan Institute of Biochemistry and Biophysics, Kazan, Russia;

Guest Editor: Maria Shishova, Saint Petersburg State University, Saint Petersburg, Russia;

Received: December 24, 2017;

Revised: March 25, 2018;

Accepted: April 26, 2018;

Copyright: (c) 2018 Lemesheva and Tarakhovskaya. This is an open-access article distributed under the terms of the License Agreement with Saint Petersburg State University, which permits to the authors an unrestricted distribution and self-archiving free of charge.

Funding: This work was supported by the Russian Foundation for Basic Research (project № 17-04-01331).

Competing interests: The authors have declared that no competing interests exist.
Phlorotannins (phaeophycean tannins) represent a specific group of secondary metabolites of brown algae. These compounds have been known since the 1960s. Described initially as yellow-colored UV-absorbing substances ("Gelbstoff") exuded from brown algae, soon they were proven to belong to phenolics (Craigie and Mc Lachlan, 1964; Sieburth and Jensen, 1969). In spite of the differing chemical structures, phlorotannins are frequently regarded as analogues of condensed tannins of higher plants because of their specific features: chelating metal ions (Connan and Stengel, 2011), absorbing UV radiation (Pavia et al., 1997), precipitating proteins and alkaloids (Stern et al., 1996; Martinez and Castaneda, 2013) and having an astringent taste (Arnold and Targett, 2000).

Natural phlorotannins are a complex mixture of water-soluble oligomers and polymers, formed by combining a different number of phloroglucinol (1,3,5-trihydroxybenzene) molecules. Phloroglucinol is synthesized in the algal cells from malonyl-CoA through the acetate-malonate (polyketide) pathway by polyketide synthase type III (Meslet-Cladière at al., 2013). Further stages of biosynthesis, leading to the oligomerization of the phloroglucinol units and the condensation of high molecular weight phlorotannins, still remain unclear, though some studies have reported that vanadium-dependent haloperoxidases might be involved in the oxidative condensation of these phenolics (Potin and Leblanc, 2006; Berglin et al., 2004; Salgado et al., 2009; Bitton et al., 2006, 2007). The polymerization process leads to the formation of different types of phlorotannins with molecular size ranging from $126 \mathrm{Da}$ (monomer molecule) to $650 \mathrm{kDa}$ (Ragan and Glombit- 
za, 1986). Generally, these compounds are divided into four classes according to the different variants of chemical bonds between the monomers (Fig. 1). The first class of phlorotannins includes fuhalols and phlorethols with ether linkages (Aryl-O-Aryl). The second class comprises fucols with phenyl linkages (Aryl-Aryl). Phlorotannins of the third class - fucophlorethols - have both ether and phenyl linkages and can be branched, and the fourth class combines the molecules with dibenzodioxin linkages - eckols and carmalols (Barre et al., 2010). The capacity of the larger molecules to form many isomeric forms gives rise to the great diversity of these compounds (Heffernan et al., 2015). There are a few reports showing that the distinct molecular size fractions $(<1$, $1-10,10-100$, and $>100 \mathrm{kDa}$ ) of phlorotannins isolated from brown algae were quantitatively different depending on the species, geographical region and thallus zone (Iken et al., 2007). Low molecular weight phlorotannins in the tissues of brown algae can be halogenated or sulfated (reviewed by Barre et al., 2010).

The content of phlorotannins in brown algal tissues varies from 0.5 to 25\% DW (Targett et al., 1995, 1998; Iken et al., 2007; Kamiya et al., 2010). This characteristic is species-specific and correlates with water salinity, nutrient availability, plant habitat, size and developmental stage, season, grazing intensity and other conditions (Ragan and Jensen, 1978; Targett et al., 1992; Steinberg, 1995; Peckol et al., 1996; Hammerstrom et al., 1998; Van Alstyne, 1988; Van Alstyne et al., 1999; Arnold and Targett, 2000; Pavia and Brock, 2000; Pavia et al., 2002; Jormalainen et al., 2003, 2005, 2008).

Algal cells usually contain a pool of soluble phlorotannins in the specialized organelles, physodes, which are supposed to be formed in the endoplasmic reticulum (ER) and Golgi apparatus. Phlorotannin precursors might be synthesized in the ER and then transferred to the Golgi for further processing (Schoenwaelder and Clayton, 2000). Histochemical studies allow us to distinguish at least two types of physodes. Representatives of the first type tend to be accumulated around the cell nucleus, while the others move to the peripheral layer of the cytoplasm and secrete their contents into the apoplast, where phlorotannins form complexes with alginic acid (Schoenwaelder and Clayton, 2000). According to Koivikko et al. (2005), the content of cell wall-bound phlorotannins in the algal tissue is an order of magnitude lower than the concentration of soluble ones. At present, the fraction of phlorotannins associated with the cell wall is almost unstudied. Besides the intracellular and cell wall-associated phlorotannins, there is also a fraction which is constantly exuded from algal cells into the ambient medium (Sieburth and Jensen, 1969; Ragan and Jensen, 1979; Jennings and Steinberg, 1994; Swanson and Druehl, 2002; Koivikko et al., 2005; Shibata et al., 2006). For several species (Eisenia bicyclis, Ecklonia kurome) it was shown that the exuded phlorotannin fraction is enriched with halogenated monomeric phenolics (2,4-dibromophenol, 2,4,6-tribromophenol and dibromo-iodophenol) (Shibata et al., 2006).

Analysis of the literature devoted to brown algal phenolics shows that the studies are focused on four main fields partially interacting with each other: 1) works dealing with the ecological roles of phlorotannins (reviewed by Amsler and Fairhead, 2006); 2) studies describing the establishment of methods of phlorotannin isolation, fractionation and identification (reviewed by Martinez and Castaneda, 2013); 3) a considerable block of works focused on the potential practical relevance of these compounds (reviewed by Catarino et al., 2017); and 4) investigation of the phlorotannin contribution to the physiology of brown algae. As the last topic is now much less studied than the others, our review is concentrated on the systematization of the data revealing the physiological functions of phlorotannins.

\section{Physiological functions of phlorotannins}

A considerable part of known phlorotannin functions allows regarding them as protective metabolites. Similar to the higher plant tannins, phlorotannins provide chemical protection against grazing (Barbehenn and Constabel, 2011; Van Alstyne et al., 1999, 2001; Pavia and Brock, 2000; Arnold and Targett, 2003; Pavia et al., 2002; Jormalainen et al., 2003, 2005). Physode-containing vegetative cells are typically located in the outer cortical layer and in the epidermis of the algal thallus (Luder and Clayton, 2004; Shibata et al., 2004, 2006), and it was shown that any damage to algal tissues caused by grazing or erosion led to the massive release of phlorotannins (presumably, the soluble fraction from physodes) (Van Alstyne et al., 1999). Pavia and Toth (2000) showed that the total phlorotannin level in the tissues of Ascophyllum nodosum increased significantly after attack of the grazing snail Littorina obtusata, but this was not the case with the isopod Idotea granulosa. This high degree of specificity of chemical responses to physical damage was previously known only for terrestrial vascular plants but not for marine algae. The efficiency of phlorotannins in providing chemical protection depends upon the size of their molecules, with the high molecular weight phlorotannin fraction $(>10 \mathrm{kDa})$ being more effective against marine herbivores than the low molecular weight $(<5 \mathrm{kDa})$ fraction (Boettcher and Targett, 1993).

Like other plant phenols, phlorotannins exhibit antioxidant properties (Hagerman, 1998; Parys et al., 2010; Surveswaran et al., 2007; Ferreres et al., 2012), and their peripheral localization and absorption spectrum imply that they may serve as UV-protectors. Ferreres et al. (2012) revealed a correlation between the antioxidative activity of phlorotannins and their species-specific chem- 
ical structure. This corresponds well with the considerable discrepancy of the data on UV-induced phlorotannin accumulation in different brown algal species. For example, exposure to UV-B radiation led to the two-fold increase of phlorotannin concentration in the tissues of A.nodosum (Pavia et al., 1997), but had no such effect on Fucus vesiculosus (Creis et al., 2015). As phlorotannin content in the tissues of F. vesiculosus is generally higher than in A.nodosum, we may suppose that being a mid-intertidal species, F. vesiculosus constitutively accumulates sunscreen substances which make it less sensitive to the increased UV radiation. A similar situation was reported for higher plants - Arabidopsis mutants permanently produce sunscreen flavonoids (Bieza and Lois, 2001). For Lessonia nigrescens (Laminariales) it was shown that UV-protective functions were mostly attributed to the cell wall- bound phlorotannin fraction (Gómez and Huovinen, 2010).

The ability of brown macrophytic algae to bind heavy metals depends on both their cell wall polysaccharides (Davis et al., 2003) and phlorotannins (Connan and Stengel, 2011). It was shown that A.nodosum phlorotannin extract collected from a site with a relatively low anthropogenic burden contained copper, cadmium, chromium and zinc. A. nodosum and F. vesiculosus exposed to an increased copper concentration demonstrated a decrease of total phenolic content and phlorotannin redistribution between the main three cell fractions, with an increase in the relative content of the cell wall-associated and exuded phlorotannins (Connan and Stengel, 2011).

Another common function of phlorotannins and polyphenols of higher plants is their contribution to cell wall formation and rigidification (Schoenwaelder and Clayton, 1999; Bidlack and Dashek, 2016) Phlorotannins are one of the main constituents of brown algal cell walls, along with alginate, fucoidan and cellulose (Schoenwaelder and Clayton, 1998, 1999). They are incorporated into the cell walls during the period of active cell growth, presumably contributing to cell wall rigidification via cross-linking reactions catalyzed by vanadium-dependent haloperoxidases (Schoenwaelder and Clayton, 2000; Arnold and Targett, 2003; Koivikko et al., 2005; Salgado et al., 2009).

Thus, several functions of phlorotannins correspond well to the functions of vascular plant phenolics. However, there are also some data implying that the spectrum of physiological action of polyphenols in brown algal cells and tissues is much wider than in the higher plants. Moreover, phlorotannins might not be considered typical secondary metabolites - most likely they combine both primary and secondary roles in cell metabolism and development (Arnold and Targett, 2002). Now we will discuss the data which do not align with the concept of phlorotannins being typical protective secondary metabolites.
First of all, the dynamics of phlorotannin metabolic turnover are not similar to those of the protective secondary compounds in vascular plants. Higher plant polyphenolics performing chemical defence are usually characterized by a minor rate of metabolic turnover, which means high initial cost of biosynthesis of these compounds, but low fixed costs for their maintenance (Coley et al., 1985). On the contrary, Arnold and Targett (2000) reported a significant turnover of phlorotannins in algal cells, both in laboratory and in natural conditions. The rate of polyphenol metabolism varied in different brown algal species, which might indicate a difference in the use of these compounds. Many species of brown algae contain an amount of phlorotannins (15-25\% DW) which appears to be too much to constitutively perform the protective functions. There are data showing that the anti-herbivory effect (Boettcher and Targett, 1993) and antioxidant properties (Heffernan et al., 2014) are mostly confined only to specific phlorotannin fractions, which might not be dominating ones. For example, Boettcher and Targett (1993) showed that high molecular weight phlorotannins were the most effective in decreasing herbivore assimilation, and according to the data of phlorotannin profiling (Steevensz et al., 2012), some brown algae contain very little of this phlorotannin fraction.

Luder and Clayton's (2004) detailed study of Ecklonia radiata showed that besides herbivory suppression, the accumulation of physodes contributes also to the wound-healing process. First of all, phlorotannins exuded from the damaged cells promote wound "clotting" by protein precipitation and also disinfect the wound due to their antibacterial effect. Then, at an early step of the regeneration process, some new medullary cells containing a considerable amount of physodes (which is generally not typical for these cells) appear in the wound region. During the next three days, the number and size of physodes in these cells increase, indicating an enhanced rate of phlorotannin biosynthesis. Finally, after the formation of the new cortical layer, the phlorotannins from the peripheral physodes are partially transferred to the cell walls (Luder and Clayton, 2004).

Phlorotannins provide chemical defense against different sorts of epiphytic organisms, which are supposed to be the natural enemies of marine macrophytes. In physiologically relevant concentrations, phlorotannins are reported to be effective against bacteria, polychaetes (Lau and Qian, 1997) and barnacles (Lau and Qian, 2000; Wikström and Pavia, 2004). Interestingly, the phlorotannin extracts taken from the two Fucus species (F. evanescens and F. vesiculosus) have the same total amount of polyphenols, but they influence the common fouling organism Balanus improvisus (Cirripedia) differently in laboratory conditions, with $F$. vesiculosus extract being much more effective (Wikström and Pavia, 2004). 


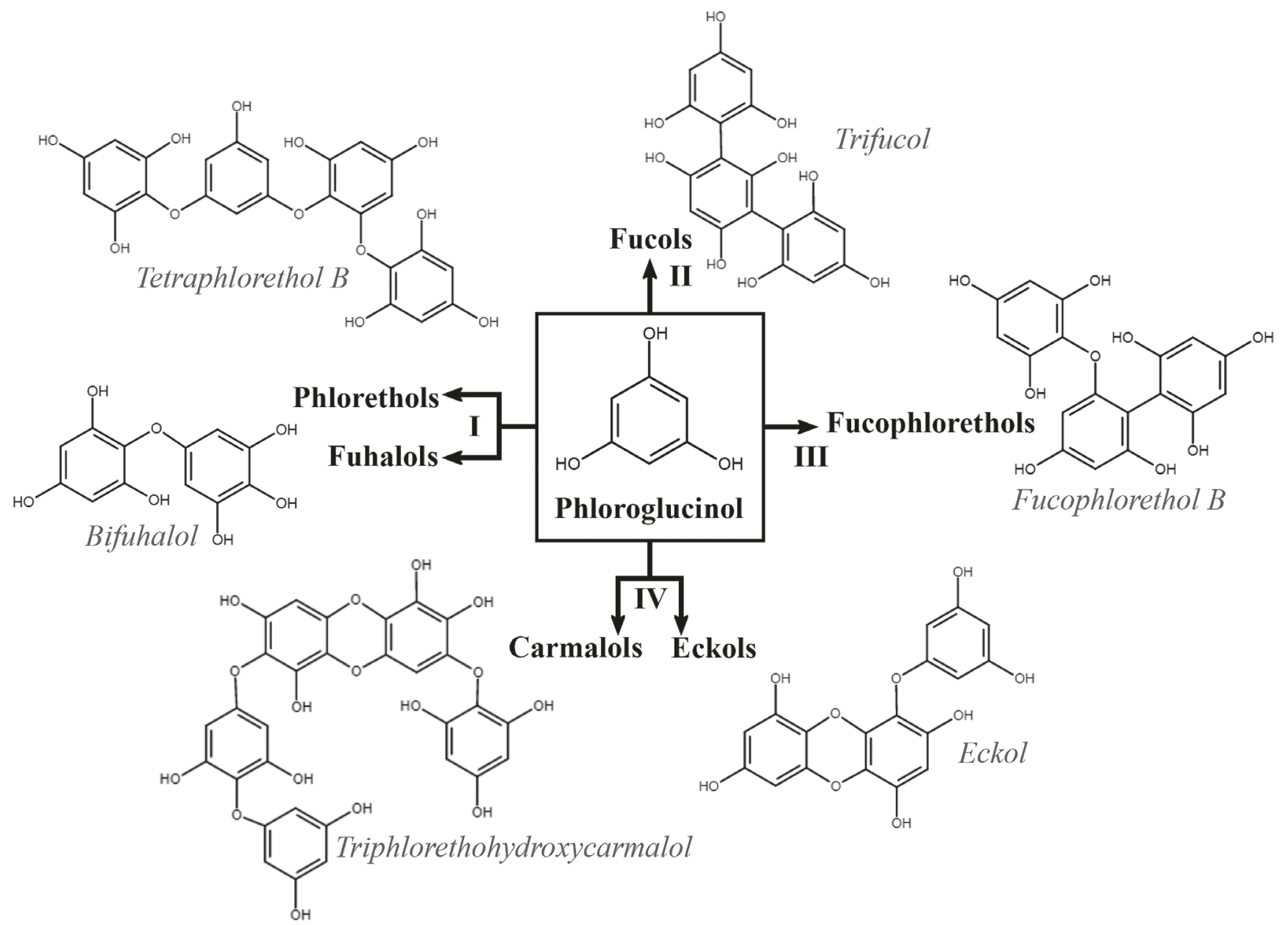

Fig. 1 Chemical structure of phloroglucinol and subunits of the four classes of phlorotannins

This can likely be explained by the different composition of the phlorotannins extracted from these two algal species. It was shown that $F$. vesiculosus contains a relatively high amount of low molecular weight phlorotannins (Steevensz et al., 2012), so we may suppose that this particular fraction provides an antifouling effect.

One of the most interesting specific functions of phlorotannins is their versatile contribution to algal early embryogenesis (Schoenwaelder and Clayton, 1998; Schoenwaelder, 2002; Potin and Leblanc, 2006; Berglin et al., 2004; Tarakhovskaya, 2014; Tarakhovskaya et al., 2017). This process is described in one of the most studied algal models - fucoid zygotes. The massive release of phlorotannins out of the zygote in the first minutes after fertilization (just before the start of cell wall formation) provides a block of polyspermy, which is crucial for later embryogenesis, because the polyspermy may lead to serious abnormalities in zygote development. Secreted polyphenols affect antherozoids by quickly reducing their motility. This process has been reported for many fucoid species (Schoenwaelder, 2002). During the first 6-10 h of fucoid zygote development, a primary cell wall is formed, and starting from $\sim 3 \mathrm{~h}$ after fertilization, as a result of the temporary intensification of biosynthesis of the cell wall matrix, the adhesive material appears on the zygote surface (Tarakhovskaya, 2014). Both the cell wall and the adhesive material contain phlorotannins as one of the main constituents. Because of the hydroxyl groups exposed to the surface of the molecule (Fig. 1), phlorotannins can replace $\mathrm{H}_{2} \mathrm{O}$ and form hydrogen bonds with the substrate. The rest of the free hydroxyl groups of phlorotannins are used to form a flexible net, structuring the adhesive via cross-linking reactions and causing its irreversible rigidification (Bitton et al., 2007; Tarakhovskaya, 2014). The first day of Fucus zygote development is accompanied by dramatic changes in the content of the low molecular weight phenolics (phloroglucinol, phloroglucinic acid, difucol, etc.), which apparently reflects the changes in the intensity of phlorotannin biosynthesis and consumption in the developmental processes (Tarakhovskaya et al., 2017). Besides their participation in the prevention of polyspermy, cell wall formation and adhesive maturation, phlorotannins are also supposed to contribute to the first asymmetric division of fucoid zygote, which takes place $\sim 20 \mathrm{~h}$ after fertilization. During this process physodes are the first structures to appear in the region of the prospec- 
tive phragmoplast and form a distinct line across the center of the zygote (Schoenwaelder and Clayton, 1998). Data imply that physodes may contribute to the sporogenesis process in some brown algal species not only as cell wall constituents. According to Phillips et al. (1994), physodes tend to be aggregated around the dividing nuclei in the central region of the immature sporangium of Lobophora variegata and several Zonaria species (Dictyotales) up to the tetranucleate stage. At the octanucleate stage, when the nuclei migrate to the periphery of the sporangium, physodes are distributed throughout the cytoplasm. Later, most of them align themselves along the prospective plane of cytokinesis, with very few remaining elsewhere in the cytoplasm (Phillips et al., 1994).

\section{Concluding remarks}

Our detailed analysis of the literature has shown that phlorotannins are still the least studied group of phenolic compounds, especially with respect to their physiological functions. The complex and diverse composition of natural phlorotannins implies that a considerable breakthrough can be reached only by changing the general approach to the study of these compounds - combining the methodical achievements with physiological implications. Many inconsistencies in the results of early studies arise from the impossibility of separating and identifying different phlorotannin species and fractions. Now the increasing efficiency in the HPLC-MS-based separation of crude or fractioned phlorotannin extracts (e.g., Steevensz et al., 2012) allows researchers to obtain much more detailed information. There are already several studies (Wikström and Pavia, 2004; Iken et al., 2007; Jormalainen et al., 2008; Gómez and Huovinen, 2010) implying that the specific physiological functions might be attributed to the specific fractions of phlorotannins, and that algal responses to environmental factors are reflected not in the changes of the total polyphenol content, but in the changes of phlorotannin profiles. We believe that studies of the correlation between the structure of these substances and their functions will allow us to take a new look at known information, thus providing better performance in the fields of both fundamental algal physiology and applied phycology.

\section{References}

Amsler, C. D., and Fairhead, V.A. 2006. Defensive and sensory chemical ecology of brown algae. Advances in Botanical Research 43:1-91. https://doi.org/10.1016/S00652296(05)43001-3

Arnold, T.M., and Targett, N. M. 2000. Evidence for metabolic turnover of polyphenolics in tropical brown algae. Journal of Chemical Ecology 26:1393-1410. https://doi. org/10.1023/A:1005588023887

Arnold, T. M., and Targett, N. M. 2002. Marine tannins: The importance of a mechanistic framework for predicting eco- logical roles. Journal of Chemical Ecology 28:1919-1934. https://doi.org/10.1023/A:1020737609151

Arnold, T. M., and Targett, N. M. 2003. To grow and defend: lack of trade-offs for brown algal phlorotannins. Oikos 100:406-408. https://doi.org/10.1034/j.16000706.2003.11680.x

Barbehenn, R. V. C., and Constabel, P. 2011. Tannins in plantherbivore interactions. Phytochemistry 72:1551-1565. https://doi.org/10.1016/j.phytochem.2011.01.040

Barre, S., Potin, P., Leblanc, C., Delage, L. 2010. The halogenated metabolism of brown algae (Phaeophyta), its biological importance and its environmental significance. Marine Drugs 8:988-1010. https://doi.org/10.3390/ md8040988

Berglin, M., Delage, L., Potin, P., Vilter, H., Elwing, H. 2004. Enzymatic cross-linking of a phenolic polymer extracted from the marine alga Fucus serratus. Biomacromolecules 5(6):2376-2383. https://doi.org/10.1021/bm0496864

Bidlack, J. E., and Dashek, W. V. 2016. Plant cell walls. Plant Cells and their Organelles 9:209-238. https://doi. org/10.1002/9781118924846.ch9

Bieza, K., and Lois, R. 2001. An Arabidopsis mutant tolerant to lethal ultraviolet-B levels shows constitutively elevated accumulation of flavonoids and other phenolics. Plant Physiology 126:1105-1115. https://doi.org/10.1104/ pp.126.3.1105

Bitton, R., Ben-Yehuda, M., Davidovich, M., Balazs, Y., Potin, P., Delage, L., Colin, C., Bianco-Peled, H. 2006. Structure of algal-born phenolic polymeric adhesives. Macromolecular Bioscience 6:737-746. https://doi.org/10.1002/ mabi.200600073

Bitton, R., Berglin, M., Elwing, H., Colin, C., Delage, L., Potin, P., Bianco-Peled, H. 2007. The influence of halidemediated oxidation on algae-born adhesives. Macromolecular Bioscience 7:1280-1289. https://doi.org/10.1002/ mabi.200700099

Boettcher, A., and Targett, N. 1993. Role of polyphenolic molecular size in reduction of assimilation efficiency in Xiphister mucosus. Ecology 74(3):891-903. doi: 10.2307/1940814

Catarino, M. D., Silva, A. M. S., Cardoso, S. M. 2017. Fucaceae: a source of bioactive phlorotannins. International Journal of Molecular Science 18:1327. https://doi.org/10.3390/ ijms18061327

Coley, P.D., Bryant, J.P., Chapin, F. S. 1985. Resource availability and plant antiherbivory defense. Science 230:895899. https://doi.org/10.1126/science.230.4728.895

Connan, S., and Stengel, D. B. 2011. Impacts of ambient salinity and copper on brown algae: 2 . Interactive effects on phenolic pool and assessment of metal binding capacity of phlorotannin. Aquatic Toxicology 104:1-13. https://doi. org/10.1016/j.aquatox.2011.03.016

Craigie, J. S., Mc Lachlan, J. 1964. Excretion of colored ultraviolet-absorbing substances by marine algae. Canadian Journal of Botany 42:23-33. https://doi.org/10.1139/b64003

Creis, E., Delage, L., Charton, S., Goulitquer, S., Leblanc, C., Potin, P., Ar Gall, E. 2015. Constitutive or inducible protective mechanisms against UV-B radiation in the brown alga Fucus vesiculosus? A Study of gene expression and phlorotannin content responses. PLOS ONE 10(6):e0128003. https://doi.org/10.1371/journal.pone.0128003

Davis, T. A., Volesky, B., Mucci, A. 2003. A review of the biochemistry of heavy metal biosorption by brown algae. Water Research 37:4311-4330. https://doi.org/10.1016/ S0043-1354(03)00293-8

Ferreres, F., Lopes, G., Gil-Izquierdo, A., Andrade, P. B., Sousa, C., Mouga, T., Valentão, P. 2012. Phlorotannin 
extracts from Fucales characterized by HPLC-DAD-ESIMSn: approaches to hyaluronidase inhibitory capacity and antioxidant properties. Marine Drugs 10: 2766-2781. https://doi.org/10.3390/md10122766

Gómez, I., and Huovinen, P. 2010. Induction of phlorotannins during UV exposure mitigates inhibition of photosynthesis and DNA damage in the kelp Lessonia nigrescens. Photochemistry and Photobiology 86:1056-1063. https://doi. org/10.1111/j.1751-1097.2010.00786.x

Hagerman, A.E., Riedl, K.M., Jones, G. A., Sovik, K. N., Ritchard, N. T., Hartzfeld, P. W., Riechel, T. L. 1998. High molecular weight plant polyphenolics (tannins) as biological antioxidants. Journal of Agricultural and Food Chemistry 46(5):1887-1892. https://doi.org/10.1021/ jf970975b

Hammerstrom, K., Dethier, M. N., Duggins, D. O. 1998. Rapid phlorotannin induction and relaxation in five Washington kelps. Marine Ecology Progress Series 165:293-305. https://doi.org/10.3354/meps165293

Heffernan, N., Nigel, P., Brunton, R. J., Fitz, G., Smyth, T.J. 2015. Profiling of the molecular weight and structural isomer abundance of macroalgae-derived phlorotannins. Marine Drugs 13:509-528. https://doi.org/10.3390/ md13010509

Heffernan, N., Smyth, T. J., Soler-Villa, A., Fitzgerald, R. J., Brunton, N. P. 2014. Phenolic content and antioxidant activity of fractions obtained from selected Irish macroalgae species (Laminaria digitata, Fucus serratus, Gracilaria gracilis and Codium fragile). Journal of Applied Phycology 27:519. https://doi.org/10.1007/s10811-014-0291-9

Iken, K., Amsler, C. D., Hubbard, J. M., McClintock, J. B. and Baker, B. J. 2007. Allocation patterns of phlorotannins in Antarctic brown algae. Phycologia 46:386-395. https:// doi.org/10.2216/06-67.1

Jennings, J. G., and Steinberg, P. D. 1994. In situ exudation of phlorotannins by the sublittoral kelp Ecklonia radiata. Marine Biology 121:349-354. https://doi.org/10.1007/ BF00346744

Jormalainen, V., Honkanen, T., Koivikko, R., Eranen, J. 2003. Induction of phlorotannin production in a brown alga: defense or resource dynamics. Oikos 103:640-650. https:// doi.org/10.1034/j.1600-0706.2003.12635.x

Jormalainen, V., Honkanen, T., Vesakoski, O., Koivikko, R. 2005. Polar extracts of the brown alga Fucus vesiculosus (L.) reduce assimilation efficiency but do not deter the herbivorous isopod Idotea baltica (Pallas). Journal of Experimental Marine Biology and Ecology 317:143-157. https://doi.org/10.1016/j.jembe.2004.11.021

Jormalainen, V., Koivikko, R., Eränen, J. K., Loponen J. 2008. Variation of phlorotannins among three populations of Fucus vesiculosus as revealed by HPLC and colorimetric quantification. Journal of Chemical Ecology 34:57-64. https://doi.org/10.1007/s10886-007-9410-2

Kamiya, M., Nishio, T., Yokoyama, A., Yatsuya, K., Nishigaki, T., Yoshikawa, S. Ohki, K. 2010. Seasonal variation of phlorotannin in sargassacean species from the coast of the Sea of Japan. Phycological Research 58:53-61. https://doi. org/10.1111/j.1440-1835.2009.00558.x

Koivikko, R., Loponen, J., Honkanen, T., Jormalainen, V. 2005. Contents of cytoplasmic, cell-wall-bound and exudes phlorotannins in the brown alga Fucus vesiculosus, with implications on their ecological functions. Journal of Chemical Ecology 31:195-209. https://doi.org/10.1007/ s10886-005-0984-2

Lau, S. C. K., and Qian, P. Y. 1997. Phlorotannins and related compounds as larval settlement inhibitors of the tubebuilding polychaete Hydroides elegans. Marine Ecology
Progress Series 159:219-227. https://doi.org/10.3354/ meps159219

Lau, S. C. K., and Qian, P.Y. 2000. Inhibitory effect of phenolic compounds and marine bacteria on larval settlement of the barnacle Balanus amphitrite amphitrite Darwin. Biofouling 16:47-58. https://doi. org/10.1080/08927010009378429

Lüder, U.H., and Clayton, M. N. 2004. Induction of phlorotannins in the brown macroalga Ecklonia radiata (Laminariales, Phaeophyta) in response to simulated herbivory - the first microscopic study. Planta 218(6):928-37. https://doi.org/10.1007/s00425-003-1176-3

Martinez, J. H., and Castaneda, H. G. 2013. Preparation and chromatographic analysis of phlorotannins. Journal of Chromatographic Science 51:825-838. https://doi. org/10.1093/chromsci/bmt045

Meslet-Cladiere, L., Delage, L., Leroux, C.J., Goulitquer, S., Leblanc, C., Creis, E., Gall E.A.; Stiger-Pouvreau, V., Czjzek, M., Potin, P. 2013. Structure/function analysis of a type III polyketide synthase in the brown alga Ectocarpus siliculosus reveals a biochemical pathway in phlorotannin monomer biosynthesis. Plant Cell 25:3089-3103. https://doi.org/10.1105/tpc.113.111336

Parys, S., Kehraus, S., Krick, A., Glombitza, K. W., Carmeli, S, Klimo, K., Gerhäuser, C., König, G. M. 2010. In vitro chemopreventive potential of fucophlorethols from the brown alga Fucus vesiculosus L. by anti-oxidant activity and inhibition of selected cytochrome P450 enzymes. Phytochemistry 71(2-3):221-9. https://doi.org/10.1016/j. phytochem.2009.10.020

Pavia, H., Cervin, G., Lindgren, A., Aberg, P. 1997. Effects of UV-B radiation and simulated herbivory on phlorotannins in the brown alga Ascophyllum nodosum. Marine Ecology Progress Series 157:139-146. https://doi. org/10.3354/meps157139

Pavia, H., and Brock, E. 2000. Extrinsic factors influencing phlorotannin production in the brown alga Ascophyllum nodosum. Marine Ecology Progress Series 193:285-294. https://doi.org/10.3354/meps193285

Pavia, H., and Toth, G. B. 2000. Inducible chemical resistance to herbivory in the brown seaweed Ascophyllum nodosum. Ecology 81:3212-3225. https://doi.org/10.2307/177411

Pavia, H., Toth, G. B., Aberg, P. 2002. Optimal defense theory: Elasticity analysis as a tool to predict intraplant variation in defenses. Ecology 83:891-897. https://doi. org/10.2307/3071898

Peckol, P., Krane, J. M., Yates, J. L. 1996. Interactive effects of inducible defense and resource availability on phlorotannins in the North Atlantic brown alga Fucus vesiculosus. Marine Ecology Progress Series 138:209-217. https:// doi.org/10.3354/meps138209

Phillips, I. A., Clayton, M. N., Harvey, A.S. 1994. Comparative studies on sporangial distribution and structure in species of Zonaria, Lobophora and Homoeostrichus (Dictyotales, Phaeophyceae) from Australia. European Journal of Phycology 29:93-101. https://doi. org/10.1080/09670269400650541

Potin, P., and Leblanc, C. L. 2006. Phenolic-based adhesives of marine brown algae. Biological Adhesives 105-124. https://doi.org/10.1007/978-3-540-31049-5_6

Ragan, M.A., and Glombitza, K.W. 1986. Phlorotannins, brown algal polyphenols. Progress in Phycological Research 4:129-241.

Ragan, M. A., and Jensen, A. 1978. Quantitative studies on brown algal phenols. II. Seasonal variation in polyphenol content of Ascophyllum nodosum (L.) Le Jol. and Fucus vesiculosus (L.). Journal of Experimental Marine Biology 
and Ecology 34:245-258. https://doi.org/10.1016/S00220981(78)80006-9

Ragan, M.A., and Jensen, A. 1979. Quantitative studies on brown algal phenols. III. Light-mediated exudation on polyphenols from Ascophyllum nodosum (L.) Le Jol. Journal of Experimental Marine Biology and Ecology 36:91-101. https://doi.org/10.1016/0022-0981(79)90102-3

Salgado, L. T., Cinelli, L. P., Viana, N. B., de Carvalho, R. T., de Souza Mourão, P. A., Teixeira, V. L., Filho, G. M. A. 2009. A vanadium bromoperoxidase catalyzes the formation of high-molecular-weight complexes between brown algal phenolic substances and alginates. Journal of Phycology 45:193-202. https://doi.org/10.1111/j.15298817.2008.00642.x

Schoenwaelder, M.E.A. 2002. The occurrence and cellular significance of physodes in brown algae. Phycologia 41(2):125-139. https://doi.org/10.2216/i0031-8884-41-2125.1

Schoenwaelder, M. E. A., and Clayton, M. N. 1998. Secretion of phenolic substances into the zygote wall and cell plate in embryos of Hormosira and Acrocarpia (Fucales, Phaeophyceae) Journal of Phycology 34:969-980. https://doi. org/10.1046/j.1529-8817.1998.340969.x

Schoenwaelder, M. E. A., and Clayton, M. N. 1999. The presence of phenolic compounds in isolated cell walls of brown algae. Phycologia 38:161-166. https://doi. org/10.2216/i0031-8884-38-3-161.1

Schoenwaelder, M. E. A., Clayton, M. N. 2000. Physode formation in embryos of Phyllospora comosa and Hormosira banksii (Phaeopbyceae). Phycologia 39:1-9. https://doi. org/10.2216/i0031-8884-39-1-1.1

Shibata, T., Kawaguchi, S., Hama, Y., Inagaki, M., Yamaguchi, K., Nakamura, T. 2004. Local and chemical distribution of phlorotannins in brown algae. Journal of Applied Phycology 16:291-296. https://doi.org/10.1023/ B:JAPH.0000047781.24993.0a

Shibata, T., Hama, Y., Miyasaki, T., Ito, M., Nakamura, T. 2006. Extracellular secretion of phenolic substances from living brown algae. Journal of Applied Phycology 18:787-794. https://doi.org/10.1007/s10811-006-9094-y

Sieburth, J. M., and Jensen, A. 1969. Studies on algal substances in the sea. II. The formation of Gelbstoff (humic material) by exudates of Phaeophyta. Journal of Experimental Marine Biology and Ecology 3:275-289. https://doi. org/10.1016/0022-0981(69)90051-3

Steevensz, A. J., Mackinnon, S. L., Hankinson, R., Craft, C., Connan, S., Stengel, D. B., Melanson, J. E. 2012. Profiling phlorotannins in brown macroalgae by liquid chromatography-high resolution mass spectrometry. Phytochemical Analysis 23:547-553. https://doi.org/10.1002/pca.2354

Steinberg, P. D. 1995. Seasonal variation in the relationship between growth rate and phlorotannin production in the kelp Ecklonia radiata. Oecologia 102:169-173. https:// doi.org/10.1007/BF00333248
Stern, J. L., Hagerman, A. E., Stainberg, P. D., Winter, F. C., Estes, J. A. 1996. A new assay for quantifying brown algal phlorotannins and comparisons to previous methods. Journal of Chemical Ecology 22:1273-1293. https://doi. org/10.1007/BF02266965

Surveswaran, S., Cai, Y., Corke, H., Sun, M. 2007. Systematic evaluation of natural phenolic antioxidants from 133 Indian medicinal plants. Food Chemistry 102:938-953. https://doi.org/10.1016/j.foodchem.2006.06.033

Swanson, A. K., and Druehl, L. D. 2002. Induction, exudation and the UV protective role of kelp phlorotannins. Aquatic Botany 73:241-253. https://doi.org/10.1016/S03043770(02)00035-9

Tarakhovskaya, E. R. 2014. Mechanisms of bioadhesion of macrophytic algae. Russian Journal of Plant Physiology 61: 23-30. https://doi.org/10.1134/S1021443714010154

Tarakhovskaya, E., Lemesheva, V., Bilova, T., Birkemeyer, C. 2017. Early embryogenesis of brown alga Fucus vesiculosus L. is characterized by significant changes in carbon and energy metabolism. Molecules 22(9): 1509. https:// doi.org/10.3390/molecules22091509

Targett, N. M., Coen, L. D., Boettcher, A. A., Tanner, C. E. 1992. Biogeographic comparisons of marine algal polyphenolics: evidence against a latitudinal trend. Oecologia 89:464-70. https://doi.org/10.1007/BF00317150

Targett, N. M., Boettcher, A. A., Targett, T. E., Vrolijk, N. H. 1995. Tropical marine herbivore assimilation of phenolicrich plants. Oecologia 103:170-9. https://doi.org/10.1007/ BF00329077

Targett, N. M., and Arnold, T. M. 1998. Predicting the effects of brown algal phlorotannins on marine herbivores in tropical and temperate oceans. Journal of Phycology 34:195205. https://doi.org/10.1046/j.1529-8817.1998.340195.x

Van Alstyne, K. L. 1988. Herbivore grazing increases polyphenolic defenses in the intertidal brown alga Fucus distichus. Ecology 69(3):655-663. https://doi.org/10.2307/1941014

Van Alstyne, K. L., Ehlig, J. M., Whitman, S. L. 1999. Feeding preferences for juvenile and adult algae depend on algal stage and herbivore species. Marine Ecology Progress Series 180:179-185. https://doi.org/10.3354/meps180179

Van Alstyne, K. L., McCarthy, J. J., Hustead, C. L., Kearns, L. J. 1999. Phlorotannin allocation among tissues of northeastern Pacific kelps and rockweeds. Journal of Phycology 35:483-492. https://doi.org/10.1046/j.15298817.1999.3530483.x

Van Alstyne, K. L., Whitman, S. L., Ehlig, J. M. 2001. Differences in herbivore preferences, phlorotannin production, and nutritional quality between juvenile and adult tissues from marine brown algae. Marine Biology 139:201-210. https://doi.org/10.1007/s002270000507

Wikström, S. A., and Pavia, H. 2004. Chemical settlement inhibition versus post-settlement mortality as an explanation for differential fouling of two congeneric seaweeds. Oecologia 138:223-230. https://doi.org/10.1007/s00442-003-1427-9 